\title{
ADAPTATION OF ANDRAGOGY IN THE EDUCATION SYSTEM OF BANGLADESH: EMULATING ANDRAGOGICAL APPROACHES OF SOUTH-EAST ASIA
}

\author{
Tasnia Rubayet, \\ Hasan Toufiq Imam ${ }^{i}$ \\ Institute of Education and Research, \\ University of Chittagong, \\ Bangladesh
}

\begin{abstract}
:
Andragogy is the art and science of assisting people in learning, as well as the study of adult education philosophy, procedures, and technology. Andragogy and economy have relation through adult education and higher education. Adult education and economic development strengthen one another. The objectives of this study are- to investigate situation of andragogy in particular fields of education of Bangladesh, to identify the ways about how approaches of andragogy in South-East Asia be redesigned in Bangladesh as a part of improvement or adaptation in those particular fields. The qualitative approach is followed in this study. Bangladesh along Vietnam and the Philippines are the countries identified as emerging economies. Situation of implementation of andragogical approach in particular educational areas of Bangladesh is not the way that is naturally expected from an emerging economy. Though andragogy has been successfully introduced and adapted in western especially European education system, as a country growing both economically and socially, Bangladesh just cannot blindly adopt the process because of the differences between economies of Bangladesh and European region. So, it will be rational to adapt and improvise the andragogical approaches followed by Bangladesh's neighboring countries which are attaining financial success and have gone through similar economic phase that resembles to economy of Bangladesh. As education system of other South Asian countries is as fragmented as Bangladesh in the case of andragogy, South East Asian countries can be better inspiration.
\end{abstract}

Keywords: andragogy, economy, development, Bangladesh, South- East Asia

${ }^{i}$ Correspondence: email tasniatasnu7@gmail.com, hasant99@gmail.com 


\section{Introduction}

Adult Education, as a subsection of other specializations in faculties of education, takes pride in its use of andragogy in the teaching and learning process. It is not the same as pedagogy, which is the art and science of educating children (Omoregie, 2021). Andragogy is the art and science of assisting people in learning, as well as the study of adult education philosophy, procedures, and technology to that purpose, according to the definition of some researchers. It is a neologism derived from the Greek terms andros (man) and agein (to lead) by similarity with pedagogy, and it implies to lead or teach adults (Krajnc, 1989).

Poland, the Federal Republic of Germany, the German Democratic Republic, the Netherlands, Czechoslovakia, and Yugoslavia were the only European nations to adopt the name until the late 1980s. When it became generally recognized that the concepts and methods of pedagogy, which were intended for child and adolescent education, were not fully suited for adult education, the need for a distinct name to indicate the practice and study of assisting adults to learn became evident. Although some knowledge gained from children's education could be applied to adults, there was a lot that couldn't. Following early growth, humans went through a series of physical and psychological changes as they grew older. They had a distinct position, obligations to others, and functions than children; a greater and typically richer body of experience, different reasons and learning requirements, and a different time scale than children. Because adult learning differed in degree and, according to many, sometimes in kind from that of children, it was important to adapt the structure of learning events to adult life (Krajnc, 1989).

Whether andragogy is a theory or not is a point of contention in the literature. Some authors are content to call it a principle or a hypothesis. A theory is a formal explanation of the principles upon which a field of study is founded, or of ideas proposed to explain a phenomenon or occurrence, or, more broadly, an opinion. Andragogy qualifies as a theory under these criteria since it has assumptions that may be called rules. It's also a theory proposed to explain the reality of adult education. A theory may also be defined as a set of assumptions, accepted principles, and procedural procedures developed to analyze, forecast, or otherwise explain the nature or behavior of a set of occurrences based on limited information. The norms of method for practice are stressed in this presentation of a theory. This might be one of the reasons Mintzberg argued that a theory is the how and why of an observable occurrence. Andragogical assumptions might be used to justify a distinct technique for adult learning; however, they ignore other adult learner connections other than age. The term "theory" refers to a hypothesis or a set of ideas meant to explain something, particularly one based on general principles unrelated to the subject of the explanation (Omoregie, 2021). 


\section{Objectives of this study}

The objectives of this study are:

1) To investigate situation of andragogy in particular fields of education of Bangladesh.

2) To identify the ways about how approaches of andragogy in South-East Asia be redesigned in Bangladesh as a part of improvement or adaptation in those particular fields.

\section{Rationale}

Andragogy and economy have relation through adult education and higher education. On the basis of adult education and higher education, it is possible to create bridge between andragogy and economy.

Andragogy can be denoted as the set of specific skills and associated knowledge which aimed at the adult education (Birzer, 2004). Andragogy also can be defined as the art and science of helping adults learn and the study of adult education theory, processes, and technology to that end (Krajinc, 1989). On the other hand, Fleming (2004) connects adult education with the economy by mentioning the role of adult education in teaching job skills, up skilling and functional literacy.

Adult education and economic development strengthen one another. Citizens will be able to play a vital role in economic development by the help of adult education and they will be empowered to be part of the society's evolution which will lead towards social cohesion. And social cohesion will lead them towards enjoyment of equal opportunities to work and having access to basic infrastructure, improved human lives' quality, self-esteem and freedom which accordingly designates transition to economic development. Ultimately, it means adult education has a deep connection with economic development (Sklias, 2017).

A research suggests that higher education institutions basically dependent on adult learners, instructors, regardless of their specializations should be acquainted with knowledge and skills in andragogy (Sogunro, 2017). Higher education is now considered as central to economic modernization and the key to competing successfully within the global economy (Peters, 2007).

Though the relation between andragogy and economy is seldom mentioned, the above statements are the proof of connection between these two phrases. Andragogy ensures development of adult through adult education and that tends towards economic development same goes for higher education. This is one of the reasons of choosing economy as the criteria of adult learning in this study.

Another reason is similarity of economic transition between Bangladesh and Southeast Asian countries. The similarity of between being emerging economy and holding the titles which has possessed by some of the Southeast Asian nation can be clarified from the study of Haque (2011). Such as: 
- Bangladesh along Vietnam and the Philippines are the countries identified as emerging economies. Emerging economies denotes as the largest, wealthiest, and fastest growing of the developing countries. Their growth factors are the use of new energy, telecommunications, and information technologies as well as rapid industrialization. In this case similarity in economy can be found between Bangladesh and other two Southeast Asian countries.

- In the 1980s, the emerging economies were mainly the "Asian Tigers" are viewed as the primary emerging economies. Among them Indonesia and South Korea are notable. Due to their rapid growth, Malaysia, Indonesia, Vietnam, Bangladesh, and the Philippines form the next wave of emerging markets and right now Bangladesh is considered to be one of the Asian Tigers in the economic arena also the stated Southeast Asian nation.

- Bangladesh is now being branded as one of the Next Eleven (N-11) economies identified by Goldman Sachs. This includes Bangladesh, Egypt, Indonesia, Iran, Mexico, Nigeria, Pakistan, the Philippines, South Korea, Turkey and Vietnam. The economy of Bangladesh is a developing market-based economy like stated countries which includes Southeast Asian nations like Indonesia, Vietnam and the Philippines. (Haque, 2011)

This is the specific reason of choosing emulation of Southeast Asian form of andragogy in Bangladeshi education system as economic transition is same in both parts recent time.

\section{Methodology}

\subsection{Approach}

The qualitative approach is followed in this study. Qualitative Research is intended to deeply explore, understand and interpret social phenomena within its natural setting. By using a qualitative researcher methodology, researchers want to collect rich information and get detailed picture of issues, cases or events (Arora and Stoner, 2009). One of the purposes of this study was to collect rich information and explicating them in the context of Bangladesh so qualitative approach is chosen as per definition. Since one of the objectives of this study was to find out the approaches and application process of andragogy, the qualitative approach has been chosen.

\subsection{Data collection}

The researcher, in this study, used secondary data. Secondary data is collected by someone who is not the researcher of a particular research. In the time of conducting secondary research the researchers may use different data from government documents, scientific papers, statistical databases and other sources and data collected from these sources is called secondary research (Panchenko, 2020). Secondary data is considered to be advantageous as it is easily accessible, time saving as the data confined in sources like 
books, journals or other documents, comparatively low cost research, increases breadth of research, generates new vision from previous research (Pérez-Sindín, 2017).

Secondary data has been collected through document analysis. Document analysis is a form of qualitative research in which documents are interpreted by the researcher to give voice and meaning around an assessment topic (Bowen, 2009). Documents are consumed and used in organized settings and those are an important part of any social scientific research project (Prior, 2016).

\subsection{Sample}

Purposeful sampling was adopted to collect data. Purposeful sampling is a technique widely used in qualitative research for the identification and selection of information-rich cases for the most effective use of limited resources (Patton, 2014). Purposeful sampling of documents was used here for finding out the specific answers to attain the objective of this study.

Literatures are reviewed in two parts. First part consists of some specific term related to study as well as analysis of situation of andragogy in four particular fields of education related to economy of Bangladesh. Second part consists of different approaches of andragogy adopted in South East Asian countries in those four fields of education along reasons for adopting them in Bangladeshi education system.

\section{Limitation}

Document analysis had several disadvantages which includes longer time interval which makes document less reliable, documents which include memory of others and have wrong information and bear message of some propaganda are not dependable. Moreover, observers and reporters of certain document may be untrained and inexperienced which is also a disadvantage of document analysis (Caulley, 1983). Biasness and inappropriateness of secondary data and lack of control over quality of such data is a huge disadvantage (Pérez-Sindín, 2017). The researchers tried to avoid these limitations.

\section{Origin and development of the concept of andragogy}

\subsection{Andragogy}

The phrase 'Andragogy' was introduced by Alexander Knapp back in 1880s and was promoted by Malcolm Knowles during 1960s via his research works. The term was denoted by "the Pedagogy of adult education" by many educators. Dusan Savicevic, established the term andragogy as a discipline, the subject of which is the study of education and learning of adults in all its forms of expression through his research (Savicevic, 1999). On the other hand, sociologists have presented their view of social change from different perspectives. William Form and Nico Wilterdink (2020) referred 
social change as change of social structure organization influenced by change of rules of behaviors, social organization or value system in general.

At least five essential principles or ideas appear to underpin andragogy:

1) A moral postulate that places the individual at the center of education while relegating the group to the margins;

2) A belief in each person's goodness, as well as the necessity to release and trust that goodness;

3) A notion that learning should lead to progress toward realizing one's full potential;

4) A conviction that autonomy and self-direction are signposts of adulthood in a democratic society;

5) A belief in the individual's ability to attain self-direction and fulfillment in the face of social, political, cultural, and historical factors (Pratt, 1993).

\subsection{Sub disciplines of andragogy}

The variety of adult education has led to the establishment of a number of subdisciplines in those countries where the term andragogy is widely used. Basic andragogy, for example, is concerned with the organization of basic adult education ideas, principles, and definitions. It is generally taught as part of an adult educator's first training program. The study of macro social factors that lead to regional and national disparities in adult education processes is referred to as comparative andragogy, or comparative adult education (Krajnc, 1989).

The notion of lifelong learning has provided adult education with fresh views on the ways and means by which people might gain the information, skills, attitudes, and values required for comprehensive human growth. Adults' experience, self-image, desire to learn, and attitudes toward learning necessitate specialized teaching and learning methods, which fall within the domain of andragogical didactics (Krajnc, 1989).

\subsection{Andragogical definition of an adult}

In the adult education literature, there is limited consensus on what makes an adult. Some authors enlist the aid of experts from other fields to address the challenge. Some believe that at a particular age, generally 18 or 21 , one becomes an adult, depending on the country. Others utilize psychological characteristics, such as emotional, social, and intellectual maturity, to define an adult. This method is sometimes hampered by the fact that maturity is linked to social and economic standing, thus young individuals who are still in school, regardless of age, are not considered adults. All of these techniques are insufficient for andragogy. In certain countries, people under the age of 18 enroll in adult education programs after finishing high school. Personal maturity is a lifetime process influenced by personal and societal requirements, rather than an absolute state that may be achieved once and for all. In any event, a young person may require more adult education than an adult. Adulthood should be defined in terms of a person's relationship to the educational process for the sake of andragogy, since this allows for a clear 
definition in terms of pedagogy. Pedagogy is concerned with the education of those who have completed or interrupted their initial education in order to participate in other major activities or take on other social roles (children and adolescents); andragogy is concerned with the education of those who have completed or interrupted their initial education in order to participate in other major activities or take on other social roles (Krajnc, 1989).

\subsection{Historical perspective of the concept of andragogy}

The development of andragogy in the Netherlands and Flanders took a different course, inspired heavily by the work of Ten Have, professor of social pedagogy at the University of Amsterdam. Ten Have regarded Lewin's work on 'planned change' as a viable third option between total liberalism and powerful central supervision of communism during the reconstruction phase following World War II, which inspired social agology and later andragology. The welfare state's small group and community activities became the primary subject of research, rather than the individual or the huge masses. Ten Have and Knowles were acquainted and admired one other's work. Ten Have's work pleased Knowles, and he regarded it as a valuable source of inspiration. Nonetheless, the wide definition of Dutch andragology as the scientific study of social change and cultural activity, guiding adults and their professional growth in the framework of civic society and the job market, was quickly restricted to adult education (Kessels, 2015).

In the year of 1970, andragology was officially acknowledged as a field of study in the Netherlands, with degrees conferred by a number of Dutch universities. Initially, the major goal was to provide academic training and research to professionals working in social work, adult cultural assistance, and community development as a scientific support. Ten Have (1986) and his successor Nijk, on the other hand, were persuaded that establishing a theoretical framework for andragology, which would underlie the new academic field, was of paramount importance. Academics and practitioners never came to an agreement on the scientific basis and relevance for day-to-day practice in this debate. Due to internal university disagreements and social changes, the formal standing as an academic subject terminated 15 years later, in 1985. The economic crisis of the 1970s hastened the change of the welfare state, which relied on trained professionals, into the notion of "caring society," which is administered entirely by volunteers. Academically qualified specialists in social and cultural community work were no longer required. Andragology was a scientific subject that has yet to gain international recognition. Departments of pedagogy, education, psychology, and business schools have taken up the study of adult, vocational, and corporate education, as they have in many other nations. Training in the disciplines of social work, welfare, and community development lost their academic foundation at university level and continued mostly at higher vocational education institutes (Kessels, 2015).

\subsection{Economy and modern concept of andragogy during industrial revolution of Europe} Modern andragogy was originated during industrial revolution in Europe. European society at that time felt the want of educating adult in a newer way to earn livelihood and 
fulfil their role in newly industrial society. Many adult educational institutions and approaches were originated for this purpose. Draper (1998) projected this condition of adult education in that time in his book 'The Metamorphoses of Andragogy'. In his statement, the researcher described that between 1700s and 1800s many factors influenced the way in which learning was organized as well as the content and location for that learning. Those factors were: the industrial revolution and the mobility of people from rural to urban areas, to work in factories and other non-traditional occupations etc. Due to increasing technology related to navigation, war, and business many private organizations were established to educate the masses of society. For instance, to educate illiterate and people with less literacy, institution like the Society for Promoting Christian Knowledge, the Society for Encouraging the Industrious Poor, and the Society for the Diffusion of Useful Knowledge etc. were established during that time, also all kinds of educational programs such as the Mechanics' Institutes of England during 1825, cooperatives, trade unions, correspondence societies, and the development of university extension programs etc. which had practical educational purposes were established too. All of these educational helped extend the educational opportunities for the working masses of society. They provided the opportunities to become literate and made people aware about the opportunities of earning in different sector. The consistent increase in adult educational programs meant that the educators related to these programs were able to observe some factors such as adults as learners, as well as the factors which motivated adults to learn, the values placed on knowledge, and the ways adults used knowledge in earning livelihood. However, initially the teaching method of the majority of these adult programs paralleled the way of teaching children. Moreover, authoritarian and lecture approach were used for teaching adults (DRAPER, 1998).

Draper's (1998) study depicts the situation of adult education was on primary situation of development and it was quite parallel to children's education. At the near end of the 1800s the phrase 'andragogy' was coined by Alexander Knapp. At that time, society felt the need of lifelong education and other sections of adult education had to be defined in new form as it was evident a different approach had to be adopted for teaching-learning of adult apart from children education or pedagogy so that the adults might be able keep pace with constant change taking place in the society and economy. In present days, andragogy is much valued in HRD (Human Resource Development) which has a great deal economic importance in present world (Kessels, 2015). Thus, andragogy was originated as an independent term beside pedagogy to teach adults in a more practical way in order to enrich their economic contribution in society. On the other hand, all of these researches show how andragogy was originated due to the change in economy and how the concept of andragogy changed according to it. 


\section{Situation of implementation of andragogical approach in four particular educational areas of Bangladesh}

Four educational areas which are related to the economy of Bangladesh are considered in this study for exploring situation of adopting andragogy in the teaching-learning process in Bangladesh.

\subsection{Teaching-learning approaches of education related to SME (Small Medium Enterprises)}

Sustainable economy consists of employment with balanced wage for every person according to their aptitude that will eliminate mass poverty. And to develop such aptitude Small Medium enterprises (SME) and Micro Small and Medium Enterprises (MSME) are necessary for the creation of entrepreneurs in large scale which will develop more employment ultimately that will be diverse and relevant according to time. This sector of entrepreneurship has important role in the developing economy of Bangladesh as it provides about 40 percent of manufacturing output, 80 percent of industrial jobs and nearly 25 percent of the total labor force in Bangladesh. SMEs have a crucial and tactical place in the economy of Bangladesh as it includes the features like relatively high labor intensity, dependence on indigenous skills and technology, growth of industrial linkage, etc. Due to this, policies and strategies to assist small entrepreneurs and to promote SME Entrepreneur Education or EE in different sectors are being provided in Bangladesh through public, private, and NGO run TVET institutions under Technical Vocational Education and Training or TVET program which is operated by Bangladesh Technical Education Board (BTEB) at Diploma and Certificate level. Most of the entrepreneur education courses are 4-year diploma courses. Though learners are well motivated and found courses interesting and teachers were also completed $90 \%$ of course instruction, both teachers and learners respond that there are a number of issues in the EE courses of TVET that are considered to be obstacles towards implementing EE courses in proper way and the would be entrepreneurs are not being benefited fully from this course due to those reasons. Major issues are:

- Teachers mostly follow lecture method to teach adults and courses are taught for real life purpose which should include more practical and adult learners' worthy strategies. The learners seldom have demonstration and other teaching-learning strategies which show learners are taught by adopting pedagogic approach and andragogy was completely ignored.

- Lack of teachers' training by following andragogical approaches as well as teachers' inexperience in entrepreneurship

- Lack of practical and more organized curricula to serve the practical purpose of entrepreneurship

- No opportunity for being familiar with unique and innovative business project to explore new opportunities in business arena etc. 
These issues lessen the impact of EE courses for SME related education which is affects entrepreneurs of small business in negative way as they struggle implement their Diploma level knowledge in real business setup as it rarely has connection to new practical studies that tells upon economic growth of individual as well as SMEs of Bangladesh (Haolader, 2015).

\subsection{Teaching-learning approaches of tourism education}

Tourism is a huge opportunity of economic development of Bangladesh and this sector has potential to introduce the country to the world with another viewpoint which will help increase foreign investment that will ultimately lead towards economic development (Sarker, 2014). Bangladesh is highly underrated in the sector of tourism. With a small land-area it has so many tourist spots, most of them are natural tourist sites. Several of these spots like Historic mosque city of Bagerhat, Ruins of the Buddhist Vihara of Paharpur are recognized as cultural and Cox's Bazar sea beach along Sundarban as natural heritage by UNESCO (List of World Heritage Sites in Bangladesh, n.d.) But in comparison to neighboring counties the number of tourist visitation is very low here. One of the reasons is lack of knowledge among mass regarding creation of opportunities in tourist spot which may be helpful for tourist as well as local business owners around that tourist spot. The National Hotel and Tourism Training Institute (NHTTI) offers courses to ensure trained personnel for hotel and tourism industry. NHTTI offers a two-year long diploma course in hotel management which is started in 1994. The Institute also provides the job training for BPC (Bangladesh Parjatan Corporation) personnel and arrange special seminar, workshop related to tourism development. Another important institution supporting the development of tourism is Bangladesh Tourism Board. But there is no education related initiative for the masses lives around tourist spot that's why many Bangladeshi citizens are unable to flourish their tourism centric business (Roy, 2015).

In the beginning of year 2000 University of Dhaka along many private universities started 'Hospitality and Tourism Management' program which includes under graduation, post-graduation, diploma level programs but in most of the institution faculty members do not have their higher academic degree precisely a Masters or $\mathrm{PhD}$ degree in the field of tourism education. Also, many of the courses or program is not designed properly to generate skill manpower in the field of tourism in Bangladesh. Experts encourage that courses and curriculum should be built on standard pedagogy for tourism related education (Ghosh, 2015).

Moreover, other barriers like lack of practical lab, lack of classroom facilities, and lack of technological support, scarcity of skilled and experienced professionals in the field of tourism education are some of the factors that obstruct producing skilled man power in the field of tourism in Bangladesh. Tourism education Bangladesh needs properly designed program and proper training on teaching-learning approach need for faculty members that will help them enrich their teaching quality (Sarker, 2014). No proper literature is found that suggests rather pedagogy or andragogy is being adopted in teaching in the field of tourism education in Bangladesh. 


\subsection{Teaching-learning approaches adopted in e-learning}

In e-learning, different educational institutions have adopted different educational approaches mostly pedagogy but none of the researches has displayed approaches of andragogy applied in any of the educational institutions. A study by Hossain \& Ahmed says that Bangladesh Open University (BOU) has a great prospect of distance/e-learning programs. BOU stands on a successful podium giving an example of ICT-based distance education and training in Bangladesh. Online education of BOU enables students who cannot travel to campus for their disability, to have access to attributed distance education. Apart from BOU, Bangladesh Technical Education Board (BTEB) offers skill based different distance study programs for 4 years in different subjects. These are offered before pandemic. Though most of the courses are said to be student-centric, use of lecture methods are evident only. (Hossain \& Ahmed, n.d.). No mention of using andragogy has been found in this study.

The research of Miah et al. (2020) reveals use of dictated, authoritarian, essentialism, individualism teaching approaches even in university education as well as teachers' consideration to move reversely from andragogy and heutagogy to old dictated, authoritarianism, essentialism, individualism teaching-learning approaches in case of teaching in online. Using of blended method that consists of previous method and andragogy or heutagogy to conduct teaching-learning in online classes is recommended in this research (Miah et al., 2020).

The interview conducted in the study of Bashir et al. revealed the participants' concerns regarding the lack of active participation in online classes. It explains in face-toface classes students are able to participate in discussions, pair-work, and group-work, but in online classes it is difficult for the teacher to engage all students. Many thinks change in pedagogy in online classes needed to change along assessment method (Bashir et al., 2021). Analysis of Shrestha et al. shows teachers from Faculty of English Language of different higher educational institution of Bangladesh think students remain passive learners in online classes conducted during Covid-19. Suggestion for blended learning in exiting pedagogy is also voiced by the teachers as well. However, the researchers suggest adoption of e-pedagogy to involve learners actively (Shrestha et al., 2021).

All of the literature above states different teaching -learning approaches as well as have recommendation of implication of different approaches including heutagogy and andragogy but there is no mention of adaptation of andragogy in teaching-learning approach in e-learning in Bangladesh.

\subsection{Teaching-learning approaches in learning English for economic purpose}

Bangladesh is a country which is now considered as one of the countries which is developing a big market place for freelancers and day by day it is becoming an important sector of economy to this country. Despite of having so many hardworking freelancers and experts in different fields of freelancing, still most of the freelancers are struggling to capture international market in expectant rate. One of the reasons behind it is lack of fluency in English. Around $26 \%$ of freelancer struggles to communicate with 
international clients as their proficiency of English is not good enough. Government needs to update existing and develop English language learning program of different levels of educational institution which may solve this issue (Rahman \& Rahman, 2017). This indicates the need of proper teaching-learning approach to teach English to the adults of Bangladesh.

Mohammad Ali conducted research to explore the practice of critical pedagogy in the undergraduate EFL (English as Foreign Language) classroom in Bangladesh in case study method and that reveals practice of traditional pedagogy in EFL classroom (Mohammad Ali, 2017). The research suggests adoption of critical pedagogy in EFL classroom in a descriptive way but there is no mention of using andragogy. Another research confirms in the teaching-learning process of Business English which comes under ESP (English for Specific Purposes) no separate pedagogy is used apart from traditional pedagogy in Bangladeshi educational institution (Khan, 2011). It is also confirmed that in the English-speaking classes of private universities in Bangladesh, learner autonomy or andragogy is not used for the purpose of teaching English. (Jamila, 2013).

All of the study above stated many teaching-learning process, but none has evidential support to confirm adoption of andragogy in the English learning classes of educational institutions of Bangladesh.

\section{Emulating andragogical approach of certain field of education of Bangladesh that executed successfully in South-East Asian counterpart}

Though andragogy has been successfully introduced and adapted in western especially European education system, as a country growing both economically and socially, Bangladesh just cannot blindly adopt the process because of the differences between economies of Bangladesh and European region. So, it will be rational to adapt and improvise the andragogical approaches followed by Bangladesh's neighboring countries which are attaining financial success and have gone through similar economic phase that resembles to economy of Bangladesh. As education system of other South Asian countries is as fragmented as Bangladesh in the case of andragogy, South East Asian countries can be better inspiration. Here analysis of andragogical approach applied in certain field of education of South East Asian nation is presented on the basis of reliable documents which will lead to certain perception about the adaptation process of andragogical approaches in the education system of Bangladesh. Four educational arenas were categorized like it is done in analysis of situation of andragogy in Bangladesh. They are-

- Acclimating andragogy in education related to SME for sustainable economy;

- Application of andragogy in tourism education;

- Andragogy for successful e-learning;

- Andragogy in learning English for economic purpose.

The countries of which field of these educational aspects are analyzed here are Indonesia, Cambodia, Singapore, Thailand etc. as most of them are middle income to 
higher income countries and Bangladesh has a target to reach the stage of middle-income country by 2030 .

\subsection{Acclimating andragogy in education related to SME for sustainable economy}

There are issues in the EE courses of TVET of Bangladesh related to SME mentioned above and new adaptation of measures are necessary for solving these issues. In this case, Indonesia can be a good example of adaptation of andragogical approach in the entrepreneurship training. The GDP of Indonesia is almost twice as big as Bangladesh and possess a position in the list of upper-middle income country and still growing at a pace that it will be one of the developed countries in near future (Economy of Indonesia, n.d.). Many Indonesian researchers have introduced teaching strategies for development of Small Medium Enterprise (SME) \& Micro Small and Medium Enterprises (MSME). Some of the steps suggested for learning about SME, based on Pancasila Ideology by Suryanti and others are given below-

- Introducing the identity of each business in informal discussions facilitated with facilitators from the community, including talking about the challenges and obstacles faced so far.

- Looking for solutions to the problems encountered. The facilitator gives direction so that the problem is solved through collaboration between group members of SME and with other members in a community by utilizing the resources available in the community

- Sharing experiences while implementing agreed solutions

- Constraints analysis for solving the problem at hand

- Improvements and conclusions.

These steps involve many andragogical approaches suggested by Knowles such as independent students, environment and conditions; utilizing previous experience; internal motivation; problem-based learning etc. which are important for developing a learning system for the would -be -entrepreneurs of SME (Suriyanti, 2020). In addition, the study of Hidayah suggests involvement of joint planning, creation learning climate, diagnosis of own learning need, purpose formulation, developing a general model and evaluation on the basis of andragoical approach that may lead would be adult entrepreneurs successful learning about different important aspects of SME (Hidayah, 2015). If Bangladesh applies these strategies in educating their adult mass about SME, it will accelerate the economic development. As a result, the pathway of achieving position of middle-income country and attaining Sustainable Development Goal (SDG) by 2030 will be much easier.

\subsection{Application of andragogy in tourism education}

One of the objectives of tourism policy 2010 of Bangladesh, arguably the most important objective, is to develop human resource for tourism sector by creating training facilities and provide them with the right directions (Roy \& Roy, 2015). In order to establish tourism as a major sector of economy aside from garments and other exporting related 
industries, the andragogical approach is the best way to follow for educating the mass depending on tourism for their livelihood. Bangladesh can follow map of Indonesia and Cambodia in chalking out a plan regarding tourism education for adult population.

Tourism contributes a large portion in the economy of Indonesia and enriches foreign exchange (Mariyono, 2017). In Indonesia, the andragogical approach has been implemented in tourist guide training program which is a crucial part of development program of Maspati Lawas tourist village, and the outcome is outstanding. The Maspati law tourist village started to become much more organized and developed from that period. Because tourist guides who attended the training program, understood what kind of activity and site visitation most tourist looking for and advised local village to organize according to that. In that training program, mixed method which includes lecture method along question answer session about relevant topics and practical learning about communication with tourists etc. is used which are considered as a strategy of andragogical approaches. These approaches of andragogy have worked well in this case and that helped tourism play vital role in Indonesian economy (Hikmah, 2020).

Tourism is considered as one of the most important industry in the economy of Cambodia (Chheang, 2008). The study of Sokchann shows implementation of andragogy in executive coaching program to expand qualities of the executive of the agencies related to tourism industries in Cambodia. And the result of this study depicts improvement of the social skills, self-awareness and self-regulation, leadership abilities, motivation as well as better recognition at work and the overall positive influence of andragogy that can make an executive successful one that will help flourish Cambodian tourist industries more. So, andragogy plays important part in the coaching of executives of tourist industry (Sokchann, 2019). As Bangladesh cannot suddenly follow West in the terms of using andragogy every sphere of tourism studies, it can just establish adult education program for tourist guide which can includes andragogical approach in the curriculum that may help each of tourist guide become more professional in giving service to the tourist. Also adapting andragogy in education for executive like Cambodia may help tourism industry flourish in a big scale.

\subsection{Andragogy for successful e-learning}

In recent times, during surge of Covid-19 e-learning has extended all over the world more than ever before. In this case, Bangladesh is not an exception. Different categories of elearning have been launched for different level of education but the similarity among most of them is pedagogy method. Even e-learning arrangement of most of adult follows pedagogy as most of the teachers are not habituated to use andragogy in normal situation and they do not know how to use it in short amount time of online classes. The literature findings described in 'Teaching-learning approaches in e-learning' in the context of Bangladesh above is the basis of these statements. Study of Guan and others show that adult learners of Singapore prefer case study most and it enhances chance of self-directed learning which is considered to be approach of andragogy. Moreover, transformative learning a reliable approach of andragogy can be successfully implied in e-learning of 
adult learners. Thus, successful e-learning can take place when face-to-face learning is not possible (Guan, 2015).

Indonesia has remarkably induced andragogy in e-learning process of adult and continuing educational aspect. Implementation of andragogy in e-learning in early childhood teachers' education program in West Java of Indonesia has remained quite successful. Proper task management and quiz are used in this program are the distinguish feature of this program which has turned this program successful. This elearning program scored around 95\% in the assessment of learning media experts and during feasibility test the feasibility level of the material expert earned a percentage of $85.33 \%$ with a very feasible category. Also, the level of feasibility from learning media experts earned a percentage of $93.75 \%$ with a very feasibility category and the amount of feasibility level of the training participants gained a percentage of $94.11 \%$ with a very feasible category. These data indicate how much effective adapting andragogy in this program is (Fahimah, 2021). Another successful implementation of andragogy was observed in the parenting education at Qolbun Salim Early Childhood Education, Jatiendah Village, Cilengkrang District, Bandung Regency of Indonesia. The mixed method of online and offline learning has been followed by the Qolbun Salim Early Childhood Education. Andragogy was applied in both cases and in this program, the parents attended as participants. They were given opportunity to ask and answer questions regarding their parenting problems either with resource persons or institutions. The time for the Zoom meeting during online program was 120 minutes consisting of 60 minutes of material, 60 minutes of questions and answers. To make it more attractive, a door prize was provided. The whole program was consisting of learner centric approach. Real life-oriented issues were discussed. For instance, the program was conducted for 2020-2021 academic years when the crisis of Covid-19 related to learning was discussed. Moreover, readiness, motivational approaches, satisfying parents' curiosity etc. were very much involved in that program. Altogether it was a complete prosperous program with implementation of andragogy in parenting education (Suwarni, 2021). Faculty of Bangladeshi educational institutions may take inspiration and apply strategies in case of higher education as well as adult and continuing education purpose especially during pandemic and new normal.

\subsection{Andragogy in learning English for economic purpose}

Bangladesh can emulate the test of English language for professionals like Thailand which is known as TOEIC as well as English teaching strategy of adults followed there which includes approaches of andragogy.

Test of English for International Communication (TOEIC) is an English language proficiency test which the employees of Thailand are encouraged to take to enhance their communication skill for business purpose. It ensures the demand of employees of Thailand in ASEAN labor market as their proficiency in English is much better as they have to take this test and have to score a good number which proves their skill of communicating fluently in English as well as opens up opportunities of employment in 
national, multinational and international business institution. The academic setup was arranged in such way where andragogy was adopted to teach English language to the adults who are working in corporate level or students of business studies and related field as well as different other fields like laws, computer, public administration etc. After that attempt the test score of TOEIC increased and with that more learners were inspired to have an employment which requires fluency in English speaking and that helped the development of economic situation of many adults as they were able to get better pay job in ASEAN job market. Thus, application of andragogy in learning English as second language developed the situation of employment in Thailand (Jaturongkachoke \& Chanseawrassamee, 2017).

Adapting the strategy of Thailand in Bangladesh which involves andragogy may help Bangladeshis have variety of job opportunity and more clients in international freelancing market place which may lead further economic development in our country like Thailand.

\section{Acknowledgment}

The authors would like to acknowledge the support and suggestion of all the faculty members of IER, University of Chittagong, especially the Honorable Director of IER Professor Dr. Mohammed Bashir Ahmed.

\section{Correspondence}

Correspondence concerning the article should be addressed to: Tasnia Rubayet, Institute of Education and Research, University of Chittagong, Chittagong University Road, Hathazari, Chittagong - 4331, Bangladesh. Email: tasniatasnu7@gmail.com

\section{Conflict of interest statement}

The authors announce that concerning this manuscript, they have no competing interest $\mathrm{s}$ and that there are no financial or financially conflicting interests to declare.

\section{About the authors}

Tasnia Rubayet has recently completed her 4-year Bachelor of Education from Institute of Education \& Research (IER) of the University of Chittagong and is currently working as an independent researcher.

Hasan Toufiq Imam is a faculty member in the Institute of Education and Research at the University of Chittagong in Bangladesh. His research interests include language acquisition, philosophical perspectives of education, and history, politics and education. ORCID ID: https://orcid.org/0000-0003-1898-1997 


\section{References}

Andragogy. (n.d.). Retrieved February 15, 2021, from Lexico: https://www.lexico.com/definition/andragogy

Arora R. \& Stoner Ch. (2009). A mixed method approach to understanding brand personality. Journal of Product \& Brand Management, 18(4), 272-283. Retrieved $\begin{array}{llll}\text { March 20, } 2021 & \text { from }\end{array}$ https://www.emerald.com/insight/content/doi/10.1108/10610420910972792/full/ht $\underline{\mathrm{ml}}$

Bashir, A., Uddin, M. E., Basu, B. L., \& Khan, R. (2021). Transitioning to online education in English Departments in Bangladesh: Learner perspectives. Indonesian Journal of Applied Linguistics, 11(1), 11-20. Retrieved September 21, 2021 https://ejournal.upi.edu/index.php/IJAL/article/view/34614

Birzer, M. L. (2004). Andragogy: Student centred classrooms in criminal justice programs. Journal of Criminal Justice Education, 15(2), 393-411. Retrieved August 10, 2021 from https://www.tandfonline.com/doi/abs/10.1080/10511250400086041

Bowen, G. A. (2009). Document analysis as a qualitative research method. Qualitative Research Journal, 9(2), 27-40. Retrieved March 23, 2021 from https://www.emerald.com/insight/content/doi/10.3316/QRJ0902027/full/html

Caulley, D. N. (1983). Document analysis in program evaluation. Evaluation and Program Planning: An International Journal, 6(1), 19-29. Retrieved March 23, 2021 from https://www.sciencedirect.com/science/article/pii/0149718983900411

Chheang, V. (2008). State and tourism planning: a case study of Cambodia. Retrieved July 14, 2021 from https://mpra.ub.uni-muenchen.de/id/eprint/25306

DRAPER, J. A. (1998). The Metamorphoses of Andragogy. CJSAE, 3-26. Retrieved $\begin{array}{lrlll}\text { February } & 17, & \text { from }\end{array}$ https://cjsae.library.dal.ca/index.php/cjsae/article/view/2011

Economy of Indonesia. (n.d.). Retrieved July 9, 2021 from Wikipedia: https://en.wikipedia.org/wiki/Economy of Indonesia

Fahimah, N., Suryadi, A., \& Saepudin, A. (2021, May). Andragogy Based E-learning Model for Early Childhood Teachers in West Java. In First Transnational Webinar on Adult and Continuing Education (TRACED 2020) (pp. 25-30). Atlantis Press. Retrieved July 11, 2021 from https://www.atlantispress.com/article/125956350.pdf

Fleming, T. (2004). The state of adult education. The Adult Learner, 21, 9-17. Retrieved August 10 , 2021 https://www.tandfonline.com/doi/abs/10.1080/02601370110059519

Form, W., \& Wilterdink, N. (2020, November 16). Social Change. Retrieved February 16, 2021, from Britannica: https://www.britannica.com/topic/social-change

Ghosh, S. K. (2015). Analyzing tourism and hospitality management in Bangladesh. Retrieved 
http://dspace.bracu.ac.bd/bitstream/handle/10361/4089/The\%20daily $\% 20$ sun $\% 20$ 24th\%20march.pdf?sequence $=1$

Guan, C., Ding, D., \& Ho, K. W. (2015). E-learning in higher education for adult learners in Singapore. International Journal of Information and Education Technology, 5(5), 348. Retrieved July 15, 2021 from https://www.researchgate.net/profile/Chong-Guan2/publication/271297790 E-

Learning in Higher Education for Adult Learners in Singapore/links/56f1793 908ae4744a91ef09d/E-Learning-in-Higher-Education-for-Adult-Learners-inSingapore.pdf

Haolader, F. A. (2015). Entrepreneurship Education in TVET for Small and Medium Enterprise Development: A Case Study in Bangladesh. Bangladesh Education Journal, 14(2), 27-44. Retrieved August 30, 2021 http://www.bafed.net/pdf/edecember2015/BAFED English Journal December 2 015.pdf\#page $=29$

Haque, A. (2011). Bangladesh as an emerging economy and lessons from East Asian Miracles. In APEA Conference South Korea. https://www.researchgate.net/profile/Ariful-Haque4/publication/317220592 Bangladesh as an Emerging Economy and Lesssons from East Asian Miracles/links/592c5f2c458515e3d474b4ac/Bangladesh-as-anEmerging-Economy-and-Lesssons-from-East-Asian-Miracles.pdf

Hidayah, I., \& Ningsih, L. R. (2015). Implementation of Capital Budgeting for MSME in Fixed Assets Investment Decisions Through Andragogy Approachment. Scientific Journal of PPI-UKM, 2(5), 219-227. Retrieved July 11, 2021 from http://kemalapublisher.com/index.php/ppi-ukm/article/view/97

Hikmah, R. K. A., \& Wahyuni, S. (2020, December). Implementation of Andragogy Approaches in Training Tourism to Develop Tourist Village. In 6th International Conference on Education and Technology (ICET 2020) (pp. 312-317). Atlantis Press. Retrieved July 14, 2021 from https://www.atlantispress.com/article/125947651.pdf

Hossain, M. A., \& Ahmed, A. Prospect of ICT-based Distance (online) Learning for Pedagogical Development in Bangladesh. Retrieved September 21, 2021 from https://www.academia.edu/download/53551958/Article for NAEM July 15.PD $\underline{F}$

Jamila, M. (2013). Use of Learner Autonomy in Teaching Speaking by Tertiary Level English Language Teachers in Private Universities of Bangladesh. ELT of IOSR Journal Humanities and Social Science (IOSR-JHSS) Canadian center science and education Volume 18 Nov-Dec 2013. Retrieved September 22, 2021 from https://www.researchgate.net/profile/Mariam-

Jamila/publication/272716861 Use of Learner Autonomy in Teaching Speakin g by Tertiary Level English Language Teachers in Private Universities of B angladesh/links/5d76ed5f299bf1cb80952f65/Use-of-Learner-Autonomy-in- 
Teaching-Speaking-by-Tertiary-Level-English-Language-Teachers-in-PrivateUniversities-of-Bangladesh.pdf

Jaturongkachoke, K., \& Chanseawrassamee, S. (2017). Andragogy: A Workplace Business English Course. NIDA Journal of Language and Communication, 22(31), 1-12. Retrieved September 27, $2021 \quad$ https://so04.tcithaijo.org/index.php/NILC/article/download/113674/88333।

Kessels, J. W. (2015). Andragogy in a knowledge society. The Routledge companion to human resource development, 13-20. Retrieved February 22, 2021 from https://research.utwente.nl/files/5597430/andragogy kessels 2015 ch 2 routledg e.pdf

Khan, B. (2011). The Importance of ESP in Bangladesh (Doctoral dissertation, East West University). Retrieved September 22, 2021 from http://dspace.ewubd.edu:8080/handle/123456789/642

Krajinc, Anna (1989): Andragogy. In C. J. Titmus (ed.): Lifelong Education for Adults: An International Handbook. Oxford: Pergamon, p. 19-21. Retrieved March 17, 2021 from https://doi.org/10.1016/B978-0-08-030851-7.50008-4

Mariyono, J. (2017). Determinants of demand for foreign tourism in Indonesia. Jurnal Ekonomi Pembangunan: Kajian Masalah Ekonomi dan Pembangunan, 18(1), 82-92. Retrieved July 12, 2021 from http://journals.ums.ac.id/index.php/IEP/article/view/2042

Miah, A. S., Kabir, M. R., \& Sultana, S. (2020). E-Learning in Bangladesh: A study of teachers' behavioral orientation and affective alignment in the Post-New Normal. Contemporary Research in Education and English Language Teaching, 2(1), 1635. Retrieved September 21, 2021 http://www.learning-gate.com/index.php/2641$\underline{0230 / \text { article/view/79 }}$

Mohammad Ali, A. T. (2017). Critical pedagogy in an undergraduate English as a foreign language classroom in Bangladesh/Mohammad Ali Azgor Talukder (Doctoral dissertation, University of Malaya). Retrieved September 22, 2021 from http://studentsrepo.um.edu.my/id/eprint/7511

Omoregie, C. (2021). The Theory and Practice of Andragogy in Adult Education. Available at SSRN 3856464.

Panchenko, L., \& Samovilova, N. (2020). Secondary data analysis in educational research: opportunities for PhD students. In SHS Web of Conferences (Vol. 75, p. 04005). EDP Sciences. Retrieved March 22, 2021 from https://www.shsconferences.org/articles/shsconf/abs/2020/03/shsconf ichtml 2020 04005/shsconf ichtml 2020 04005.html

Patton, M. Q. (2014). Qualitative research \& evaluation methods: Integrating theory and practice. Retrieved March 23, 2021 from https://study.sagepub.com/patton4e/help

Pérez-Sindín, X. $(2017,4)$. Secondary Data sources: advantages and disadvantages. (M. Allen, Ed.) The SAGE Encyclopedia of Communication Research Methods, 1578-1579 https://www.researchgate.net/deref/http\%3A\%2F\%2Fdx.doi.org\%2F10.4135\%2F9 $\underline{781483381411 . n 557}$ 
Peters, M. A. (2007). Higher education, globalisation and the knowledge economy: Reclaiming the cultural mission. Ubiquity, 2007(May). Retrieved March 16, 2021 from https://dl.acm.org/doi/pdf/10.1145/1267047.1276155

Pratt, D. D. (1993). Andragogy After Twenty-five Years. New directions for adult and continuing education, 57, 15-23. Retrieved October 02, 2021 from https://papers.ssrn.com/sol3/papers.cfm?abstract id=3856464

Prior, L. (2016). Using documents in social research. Qualitative research, 171-185. Retrieved March 23, 2021 from https://books.google.com/books?hl=en\&lr=\&id=9FALDAAAQBAI\&oi=fnd\&pg=P A171\&dq=Using+documents+in+social+research\&ots=9oaAjy8B5E\&sig=z9j61xiN Lv9J-VWtYvmON1MfLFk

Rahman, M. A., \& Rahman, M. M. (2017). Factors, Impacts, Problems and Solutions of Freelance Earning in the context of Bangladesh. Business $\mathcal{E}$ Entrepreneurship Journal, 6(1), 1-13. https://www.scienpress.com/Upload/BEJ/Vol\%206 1 1.pdf

Roy, S. C., \& Roy, M. (2015). Tourism in Bangladesh: Present status and future prospects. International Journal of Management Science and Business Administration, 1(8), 53-61. Retrieved July 12, 2021 from http://citeseerx.ist.psu.edu/viewdoc/download?doi=10.1.1.885.7868\&rep=rep1\&ty pe=pdf

Sarker, J. U. (2014). Problems and prospects of quality education on tourism in Bangladesh: a particular emphasis on the tourism and hospitality management (THM) department of The People's University of Bangladesh (PUB). Retrieved $\begin{array}{llll}\text { September } & 20, & \text { from }\end{array}$ http://dspace.bracu.ac.bd/xmlui/bitstream/handle/10361/3575/11264013.pdf?sequ $\underline{\text { ence }=1}$

Savicevic, D. (1999). Understanding Andragogy in Europe and America: Comparing And Contrasting. Comparative Adult Education 1998. The Contribution of ISCAE to an Emerging Field of Study. (pp. 97-119). Ljubljana: Slovenian Inst. for Adult Education, Ljubljana. International Society for Comparative Adult Education, Bamberg (Germany). Retrieved February 24, 2021 https://www.google.com/webhp?hl=en\&sa=X\&ved=0ahUKEwj1zOSK1K7zAhWa 1EsFHYRBBSMQPAgI

Shrestha, S., Haque, S., Dawadi, S., \& Giri, R. A. (2021). Preparations for and practices of online education during the Covid-19 pandemic: A study of Bangladesh and Nepal. Education and Information Technologies, 1-23. Retrieved September 21, 2021 from https://link.springer.com/article/10.1007/s10639-021-10659-0

Sklias, P., \& Chatzimichailidou, G. (2017). Adult Education and Economic

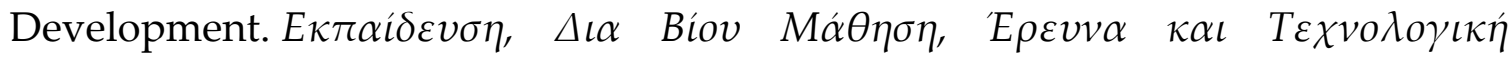

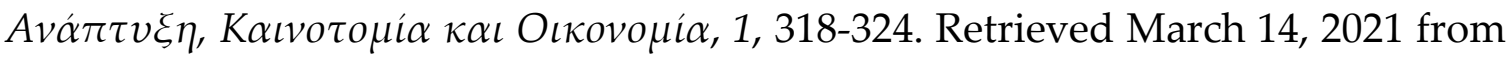
http://eproceedings.epublishing.ekt.gr/index.php/inoek/article/view/797 
Sogunro, O. A. (2017). Quality Instruction as a motivating factor in higher education. International Journal of Higher Education, 6(4), 173-184. Retrieved March 15, 2021 from https://eric.ed.gov/?id=EJ1151832

Sokchann, P., Bhaumik, A., Tamjis, M. R., \& Raju, V. (2018). Descriptive Study on Cambodian Tourism Industry towards Boosting its Economy Using Andragogy as Mediating Variable. Eurasian Journal of Analytical Chemistry, 13(6), 458-465. Retrieved July 14,2021 from https://www.lincoln.edu.my/pdf/faculty members/Descriptive\%20Study\%20on. pdf

Study at Qolbun Salim Early Childhood Education. In International Conference Universitas Pekalongan 2021 (Vol. 1, No. 1, pp. 233-240). Retrieved July 11, 2021 from https://www.proceeding.unikal.ac.id/index.php/icunikal2021/article/view/670

Suryanti, N., Wahjoedi, W., Utomo, S. H., Haryono, A., \& Nurhuda, N. (2020). Using Andragogy Approach to Transfer Pancasila Values in Economic Learning. Jurnal Pendidikan Ekonomi, 13(2), 108-115. Retrieved July 14, 2021 from http://journal2.um.ac.id/index.php/jpe/article/view/12094

Suwarni, R., Ardiwinata, J. S., \& Saripah, I. (2021). Application of Andragogy Principles to The Covid-19 Pandemic Period Parenting Program; Case Study at Qolbun Salim Early Childhood Education. In International Conference Universitas Pekalongan 2021 (Vol. 1, No. 1, pp. 233-240). Retrieved July 11, 2021 from https://www.proceeding.unikal.ac.id/index.php/icunikal2021/article/view/670 

will be applied to their work. Under the terms of this license, no permission is required from the author(s) or publisher for members of the community to copy, distribute, transmit or adapt the article content, providing a proper, prominent and unambiguous attribution to the authors in a manner that makes clear that the materials are being reused under permission of a Creative Commons License. Views, opinions and conclusions expressed in this research article are views, opinions and conclusions of the author(s). Open Access Publishing Group and European Journal of Education Studies shall not be responsible or answerable for any loss, damage or liability caused in relation to/arising out of conflicts of interest, copyright violations and inappropriate or inaccurate use of any kind content related or integrated into the research work. All the published works are meeting the Open Access Publishing requirements and can be freely accessed, shared, modified, distributed and used in educational, commercial and non-commercial purposes under a Creative Commons Attribution 4.0 International License (CC BY 4.0). 